简易一锅合成新型 5-取代 P,O-型吲哚膦配体及其应用于钯催化 芳基氯 Suzuki-Miyaura 偶联反应

\author{
梁文斌 ${ }^{\dagger}, a$ 杨宗潮 ${ }^{\dagger}, b \quad$ 蔡珮盈 ${ }^{a}$ 苏秋铭 ${ }^{b}$ 广福儿*,a,b \\ ( ${ }^{a}$ 香港中文大学化学系 香港) \\ ( ${ }^{b}$ 香港理工大学应用生物及化学科技系 香港)
}

\begin{abstract}
摘要 从容易获得且便宜的原材料出发, 通过简单的一锅式组装方法合成了一种新的 P,O-型颉哚基膦配体, 并将其用 于钯催化的芳基氯 Suzuki-Miyaura 交叉偶联反应，结果显示配体上的 “取代基” 能促进该反应的活性，其钯催化剂载 量可降至 $0.01 \mathrm{~mol} \%$.
\end{abstract}

关键词 钯; 配体设计; 交叉偶联; 膦; P,O-型配体

\title{
Facile One-Pot Assembly of New 5-Substituted P,O-Type Indolylphosphine Ligands for Palladium-Catalyzed Suzuki-Miyaura Cross-Coupling of Aryl Chlorides
}

\author{
Leung, Man Pan ${ }^{\dagger, a} \quad$ Yeung, Chung Chiu ${ }^{\dagger, b} \quad$ Choy, Pui Ying ${ }^{a} \quad$ So, Chau Ming ${ }^{b}$ \\ Kwong, Fuk Yee ${ }^{*, a, b}$ \\ ( ${ }^{a}$ Department of Chemistry, The Chinese University of Hong Kong, Hong Kong) \\ ( ${ }^{b}$ Department of Applied Biology and Chemical Technology, The Hong Kong Polytechnic University, Hong Kong)
}

\begin{abstract}
A series of P,O-type indolylphosphine ligands with different substituted variants have been synthesized by a simple one-pot protocol from readily available and inexpensive materials. These ligands show "substituent effect" with respected to the efficacy in promoting palladium-catalyzed Suzuki-Miyaura cross-coupling of aryl chlorides. This new Pd/L1 catalyst system particularly allows the catalyst loading reaching the level of $0.01 \mathrm{~mol} \% \mathrm{Pd}$.

Keywords palladium; ligand design; cross-coupling; phosphine; P,O-ligand
\end{abstract}

\section{Introduction}

Palladium-catalyzed cross-coupling is one of the most important synthetic tools for constructing aromatic carbon-carbon bonds. Among Suzuki-Miyaura, Negishi, Kumada, Stille, Hiyama cross-couplings and others in relevance, ${ }^{[1]}$ Suzuki-Miyaura reaction is found to be the most useful synthetic method, for instance of their widespread applications in pharmaceutical, material, and agricultural syntheses. ${ }^{[2]}$ The rule of thumb of enhancing the catalytic efficiency for a coupling reaction is to employ ancillary ligands equipping with appropriate steric and electronic environments. ${ }^{[3]}$ A number of brilliant chemists have put huge effort towards the design and modification of phosphine ligands, such as $\mathrm{Fu},{ }^{[4]}$ Hartwig, ${ }^{[5]}$ Buchwald, ${ }^{[6]}$ Ackermann, ${ }^{[7]}$ Beller, ${ }^{[8]}$ Kwong, ${ }^{[9]}$ Stradiotto, ${ }^{[10]}$ Tang, ${ }^{[11]}$ Zhang, ${ }^{[12]} \mathrm{Ma}^{[13]}{ }^{[1}$ ipshutz, ${ }^{[14]} \mathrm{Kapdi}^{[15]}$ and other groups. ${ }^{[16]}$ Tailor-made phosphine ligands aiming at tackling difficult Suzuki-Miyaura coupling are generally electron-rich and steric bulky, in which they are actually devised to favorably cater the oxidative addition (O.A.) and reductive elimination (R.E.) steps in a catalytic cycle, respectively. The unsaturation of a $\mathrm{Pd} /$ ligand complex is believed to offer more spatial availability for initial substrate

\footnotetext{
* Corresponding author. E-mail: fykwong@cuhk.edu.hk

Received May 26, 2020; revised July 3, 2020; published online July 15, 2020.

Dedicated to Professor Henry N. C. Wong on the occasion of his 70th birthday.

Project supported by the Guangdong Basic and Applied Basic Research Foundation (No. 2019A1515011357), and the General Research Fund (GRF) from Research Grants Council of Hong Kong (RGC) (No. 14304519).

广东省基础与应用基础研究专项资金(No. 2019A1515011357)以及中国香港研究资助局优配研究金(No. 14304519)资助项目.

$\dagger$ 共同第一作者(These authors contributed equally to this work).
} 
binding, and allow the following oxidative addition to kick start. While bulky monophosphine ligands would generate the coordinative unsaturated Pd complex, they have limited adjustability for stabilizing the highly active yet unstable low-valent and low-coordinate Pd metal center, especially at a high reaction temperature or under prolonged reaction time. ${ }^{[1 \mathrm{a}-1 \mathrm{c}, 17]}$ The decomposition of this labile Pd complex often leads to the formation of inactive Pd black and therefore suppresses the ultimate catalytic performance. In order to deal with this problematic issue, we are interested to develop a coping strategy of crafting a weakly coordinating group to the ligand skeleton. The proximal hard donor moiety is conceivable to realize the complementary stabilization of the highly active palladium center and hence a better Pd catalyst longevity would be resulted. ${ }^{[18]}$

Hemilabile P,O-type ligand embodies both hard oxygen and soft phosphorus donor atoms. ${ }^{[19]}$ The hard oxygen atom weakly binds to the soft Pd center in providing extra metal complex stability and also allows possible dissociation for offering vacant site whenever needed. ${ }^{[17,19-20]}$ The first successful example of P,O-type ligand for promoting Suzuki-Miyaura coupling of aryl chlorides was reported by Guram/Bei and co-workers in 1999 (Figure 1). ${ }^{[21]}$ Later, a ferrocenyl ligand embedded an acetal group was disclosed by Hor and co-workers, ${ }^{[22]}$ in which this ligand was found to be effective in the cross-coupling of aryl chlorides (Figure 1). The X-ray crystal structures of Guram/Bei's and Hor's Pd-ligand complexes were shown to have $\mathrm{P}-\mathrm{Pd}-\mathrm{O}$ coordination. Our research group also expressed interest in developing new series of P,O-type ligand bearing hemilabile amido group for cross-coupling reaction. ${ }^{[23]}$ These ligands exhibited high efficacy in aromatic $\mathrm{C}-\mathrm{C}$ and $\mathrm{C}-$ $\mathrm{N}$ bond-forming processes even under low catalyst loading. An independent investigation of P,O-type hemilabile ligands bearing amido group was also reported by Dai and co-workers in $2004{ }^{[24]}$ Such series of ligands were later modified by a self-assisted molecular editing process. In 2009, McNulty and co-workers ${ }^{[25]}$ reported a new trialkylphosphine associated with a proximal hydroxyl group for cross-coupling of aryl chlorides. An interesting ligand effect was postulated that the remote 4-hydroxyl substituent was suggested to stabilize the Pd complex in a boat conformation, while it could be easily isomerized to regenerate the active monodentate $\mathrm{Pd}$ complex in a chair conformer. Recently, an optically active ferrocenyl ligand was reported by Lang and co-workers ${ }^{[26]}$ for tackling the difficult steric hindered biaryl synthesis under SuzukiMiyaura reaction conditions. Indeed, it is highly desirable if the tailor-made phosphines can be easily accessed and fine-tuned in a cost-effective and step-economical synthetic pathway. Inspired by our previous success in dealing with challenging cross-coupling reactions, ${ }^{[27]}$ we are interested to further explore new P,O-type indolylphosphine ligands for Suzuki-Miyaura cross-coupling of aryl chlorides.

\section{Results and discussion}

The newly designed ligand entities are illustrated to have a "lock-on \& lock-off" switching ability, in which they are envisioned to offer awaiting coordination and thus to enhance catalyst longevity of the resulting unsaturated $\mathrm{Pd}$ complex (Figure 2a). The $\mathrm{P}$ donor electron-richness can be easily tuned to reach synergistic outcome by altering the substituent at the 5-position of indole core. We attempted to prepare a variety of 5-substituted indolylphosphines using a one-pot multi-step strategy (Figure 2b). These new ligands were directly assembled from readily available and inexpensive starting materials. Direct $\mathrm{N}-\mathrm{H}$ deprotonation of commercially available 5-substituted indoles were attained by sodium hydride and the main ligand scaffolds

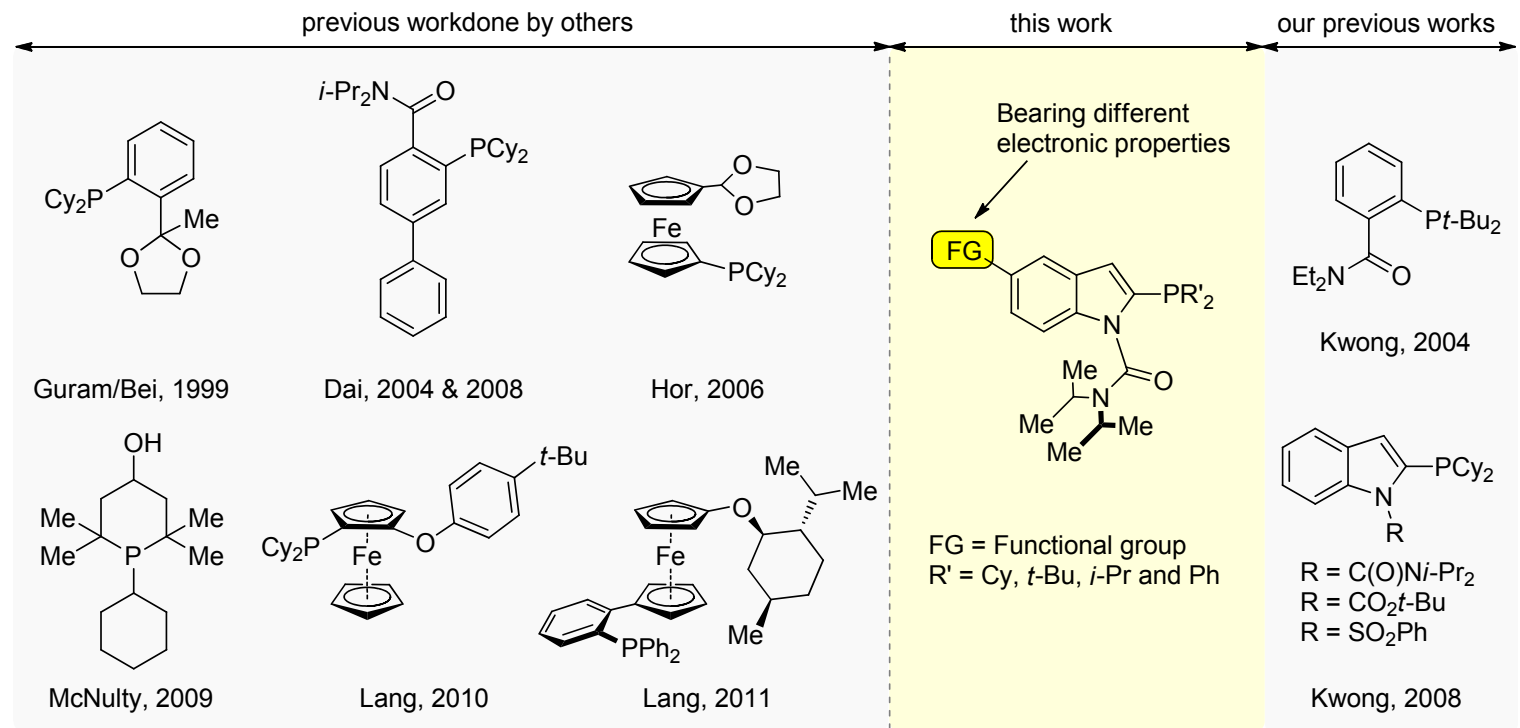

Figure 1 Selected examples of hemilabile P,O-type ligands particularly for Pd-catalyzed Suzuki-Miyaura coupling of aryl chlorides and present study 
were then generated by subsequent reaction with $N, N$ diisopropylcarbamoyl chloride. The desired ligands were afforded in good yields by the following lithiation and trapping with chlorodiphenylphosphine or chlorodialkylphosphines. It should be noted that the purification of target ligands was straightforwardly achieved by easily washing with methanol. No tedious crystallization process or column chromatographic purification step was required. Hence the possible industrial process synthesis is noted to be practicable.

With the new P,O-type indolylphosphine ligands in hand, we first evaluated their efficacy in Suzuki-Miyaura reaction using non-activated 4-chlorotoluene and steric hindered 2,6-dimethylphenylboronic acid as benchmark substrates (Scheme 1). It is interesting to show that the remote 5-phenyl group of the ligand had negative effect towards the cross-coupling efficiency (L2 vs. L7). The electron-withdrawing 5-halo-substuituted groups even further suppressed the reactivity (L3 and L4 vs. L7). These inferior results are probably due to the diminishing of electron-richness of $\mathrm{P}$ donor atom and hence decreasing the rate of O.A. of electrophile. Therefore, it is not surprised that the stronger electron-withdrawing 5-trifluoromethyl group afforded even a lower product yield (L5). On contrary to the electron-deficient substituents, the incorporation of electron-donating 5-methyl or 5-methoxyl group increased the efficiency of the ligands (L1 and L6). The electron-rich moiety enhanced the election-richness of $\mathrm{P}$ (a) A coping strategic design

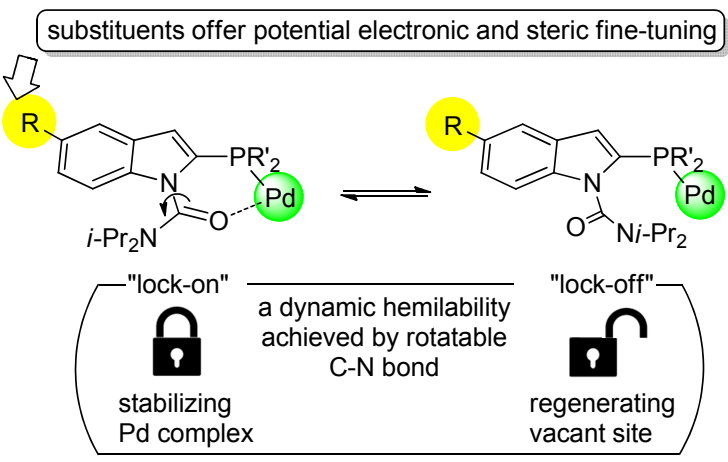

(b) Attempt one-pot synthesis of ligands
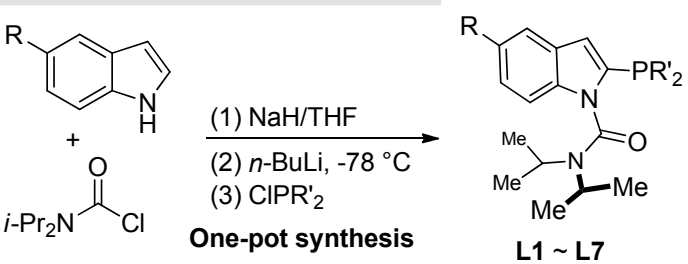

L1, R = MeO, R' = Cy, 69\%; L2, R = Ph, R' = Cy, 64\%;

L3, R = F, R' = Cy, 56\%; L4, R = Cl, R' = Cy, 79\%;

L5, R = $\mathrm{CF}_{3}, \mathrm{R}^{\prime}=\mathrm{Cy}, 50 \%$; L6, R = $\mathrm{CH}_{3}, \mathrm{R}^{\prime}=\mathrm{Cy}, 67 \%$;

L7, R = H, R' = Cy, 70\%; $t$-Bu-L1, R = OMe, R' = $t$-Bu, 71\%;

$i-\mathrm{Pr}-\mathrm{L} 1, \mathrm{R}=\mathrm{OMe}, \mathrm{R}^{\prime}=i-\mathrm{Pr}, 75 \% ; \mathrm{Ph}-\mathrm{L} 1, \mathrm{R}=\mathrm{OMe}, \mathrm{R}^{\prime}=\mathrm{Ph}, 75 \%$

Figure 2 Our rational ligand design and attempt one-pot synthesis of new P,O-type indolylphosphine ligands

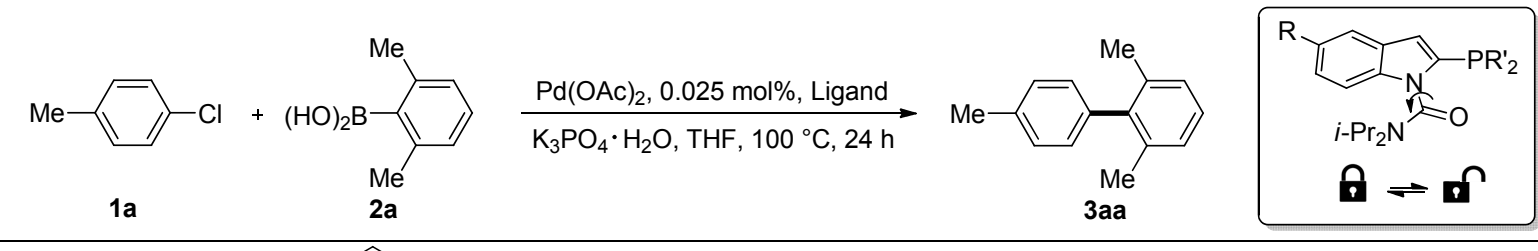<smiles>COc1ccc2c(c1)cc(P(=O)(O)C(C)C)n2C(=O)NC(C)C</smiles>

L1, $82 \%$

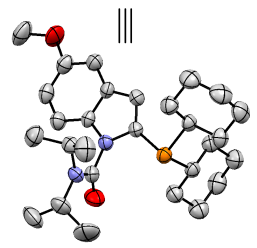

CCDC 2003554

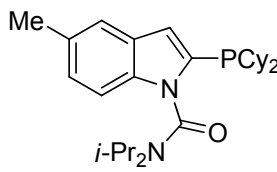

L6, $80 \%$<smiles>CCCCc1cc2cc(-c3ccccc3)ccc2n1C(=O)NC(C)C</smiles>

L2, $55 \%$

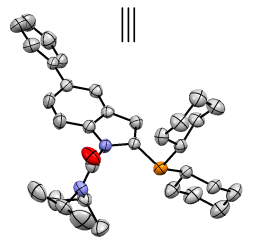

CCDC 2003552

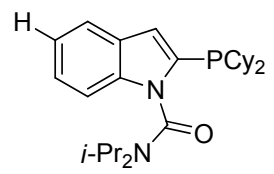

L7, $76 \%$<smiles>CC(C)NC(=O)NC(=O)n1c(P(=O)(O)c2ccccc2)cc2cc(F)ccc21</smiles>

L3, 54\%

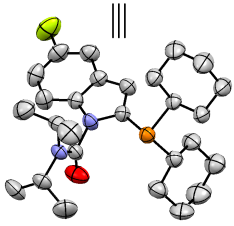

CCDC 2003553<smiles>CCCCC(=O)N(CCCC)c1cc2cc(OC)ccc2n1C(=O)NC(C)C</smiles>

t-Bu-L1, 32\%<smiles>CC(C)NC(=O)n1c(P(=O)(O)C(C)C)cc2cc(Cl)ccc21</smiles>

L4, $43 \%$

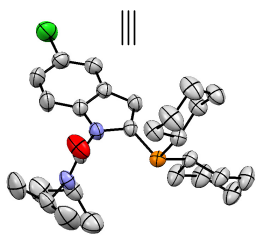

CCDC 2003551<smiles>COc1ccc2c(c1)cc(PC(=O)c1ccccc1)n2C(=O)NC(C)C</smiles>

i-Pr-L1, 48\%<smiles>CCCCC(=O)c1cc2cc(C(F)(F)F)ccc2n1C(=O)NC(C)C</smiles>

L5, $36 \%$

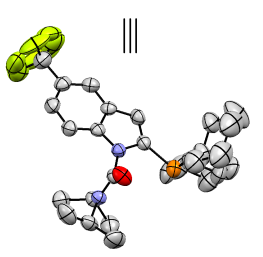

CCDC 2003550<smiles>COc1ccc2c(c1)cc(-c1ccccc1)n2C(=O)NC(C)C(F)(F)F</smiles>

Ph-L1, trace

Scheme 1 A survey of new P,O-type ligands for Suzuki-Miyaura coupling of aryl chlorides and the corresponding ORTEP representation of X-ray crystal structures (all hydrogens are omitted for clarity)

Reaction conditions: 4-chlorotoluene (1.0 mmol), 2,6-dimethylphenylboronic acid (1.5 mmol), Pd : ligand $(1: 3), \mathrm{K}_{3} \mathrm{PO}_{4} \bullet \mathrm{H}_{2} \mathrm{O}(3 \mathrm{mmol})$, and THF (3 mL) were stirred at $100{ }^{\circ} \mathrm{C}$ for $24 \mathrm{~h}$ under $\mathrm{N}_{2}$. Isolated yields of 3aa were reported full-stop 
donor and provided a stronger $\sigma$-donation to $\mathrm{C}-\mathrm{Cl} \sigma^{*}$ anti-bonding orbital, leading to the ease of bond breaking. The less steric bulky and electron-rich $i$-Pr-L1 and Ph-L1 showed decreasing trend on the activity when compared to L1. Nevertheless, further increase of the steric bulkiness and electron-richness did not give a better result ( $t$-Bu-L1). To our delight, single crystals of ligands L1 to L5 were obtained for X-ray crystallographic analysis (Scheme 1). The carboamoyl oxygen points in a perpendicular direction towards the indole plane.

Having identified the effective ligand, we next surveyed the substrate scope of aryl chlorides by employing the newly developed Pd/L1 catalyst system (Table 1). Nonactivated aryl chlorides were found applicable under the catalyst loading of $0.025 \mathrm{~mol} \%$ (Table 1, Entry 1). The catalyst loading for the activated aryl chlorides were able to be further reduced to $0.01 \mathrm{~mol} \%$ in achieving good-toexcellent product yields (Table 1, Entries 7 9). To the best of our knowledge, $\mathbf{L 1}$ is one the most efficient $\mathrm{P}, \mathrm{O}-$ type ligands for general Suzuki-Miyaura cross-coupling of aryl chlorides. Keto, aldehydo, ester and nitrile functionality were all well-tolerated under these reaction conditions (Table 1, Entries 5 9).

Table 1 Palladium-catalyzed Suzuki-Miyaura coupling of aryl chlorides ${ }^{a}$

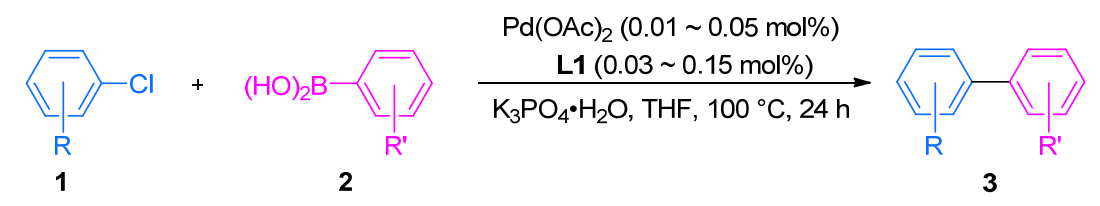

\begin{tabular}{|c|c|c|c|c|c|}
\hline Entry & $\mathrm{ArCl}$ & $\operatorname{Ar}^{\prime} \mathrm{B}(\mathrm{OH})_{2}$ & Product & $\mathrm{Pd} / \mathrm{mol} \%$ & Yield $^{b} / \%$ \\
\hline 1 & & $\mathrm{O})_{2} \mathrm{~B}$ & & 0.025 & 82 \\
\hline 2 & & & & 0.05 & 93 \\
\hline 3 & & & & 0.05 & 83 \\
\hline 4 & & & & 0.05 & 87 \\
\hline 5 & & 124 & & 0.02 & 90 \\
\hline 6 & & (1) & & 0.02 & 93 \\
\hline 7 & & & & 0.01 & 87 \\
\hline 8 & & & & 0.01 & 94 \\
\hline 9 & & & & 0.01 & 83 \\
\hline
\end{tabular}

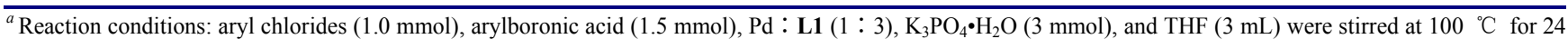
$\mathrm{h}$ under $\mathrm{N}_{2} \cdot{ }^{b}$ Isolated yields were reported. Reaction times were not optimized for each substrate. 
To further probe the generality of $\mathbf{L} 1$, a range of heteroaryl chlorides were then examined (Table 2). In fact, heteroaryl chlorides having adjacent nitrogen donor atom generally have deleterious to the Pd complex, in which the catalyst is rendered coordinative saturated. This situation becomes more vital especially under a very low catalyst concentration. Gratifyingly, P,O-type L1 still maintained comparable efficacy as the cases of simple chloroarenes. Pyridyl and quinolyl chlorides were applicable under these optimal reaction conditions (Table 2, Entries 1 5). It is worthy to note that free $\mathrm{NH}$ indole substrate was coupled smoothly under $0.05 \mathrm{~mol} \%$ catalyst loading leading to $91 \%$ product yield (Table 2, Entry 6). No competitive $\mathrm{C}-\mathrm{N}$ bond formation was observed for this entry. It is believed that the dynamic hemilability of $\mathbf{L} \mathbf{1}$ provides transient "lock-on" coordination to avoid excessive substrate binding scenario of the $\mathrm{Pd}$ complex by nitrogen-containing coupling partners.

\section{Conclusion}

In summary, we have established a facile synthetic pathway for assembling new P,O-type indolyl phosphines. This one-pot procedure allowed us to utilize readily available and inexpensive starting materials directly. By employing the newly developed $\mathrm{Pd} / \mathbf{L} \mathbf{1}$ catalyst system, the
Suzuki-Miyaura coupling of aryl/heteroaryl chlorides proceeded well. Particularly noteworthy is that the catalyst loading was found able to reach $0.01 \mathrm{~mol} \% \mathrm{Pd}$. This record represents one of the lowest catalyst loadings achieved so far of P,O-type ligand for general Suzuki-Miyaura coupling of aryl chlorides. Further investigations and applications of this ligand series for tackling difficult and unexplored coupling processes are underway.

\section{Experimental section}

\subsection{General considerations}

Unless otherwise noted, all the reagents were purchased from commercial suppliers and used without further purification. Tetrahydrofuran (THF) was freshly distilled from sodium and sodium benzophenone ketyl under nitrogen. ${ }^{[28]}$ All bases were used as received without grinding. A new bottle of $n$-butyllithium was used (note: since the concentration of $n$-BuLi from old bottles may vary, a titration is highly recommended prior to use). All Pd-catalyzed cross-coupling reactions were performed in a resealable screw-capped Schlenk flask (approx. volume $20 \mathrm{~mL}$ ) in the presence of a Teflon-coated magnetic stir bar. Thin-layer chromatography (TLC) was performed on precoated silica gel 60 F254 plates. Silica gel $(70 \sim 230$ and $230 \sim 400$ mesh) was used for flash column chromatography. Melting

Table 2 Palladium-catalyzed Suzuki-Miyaura coupling of heteroaryl chlorides ${ }^{a}$

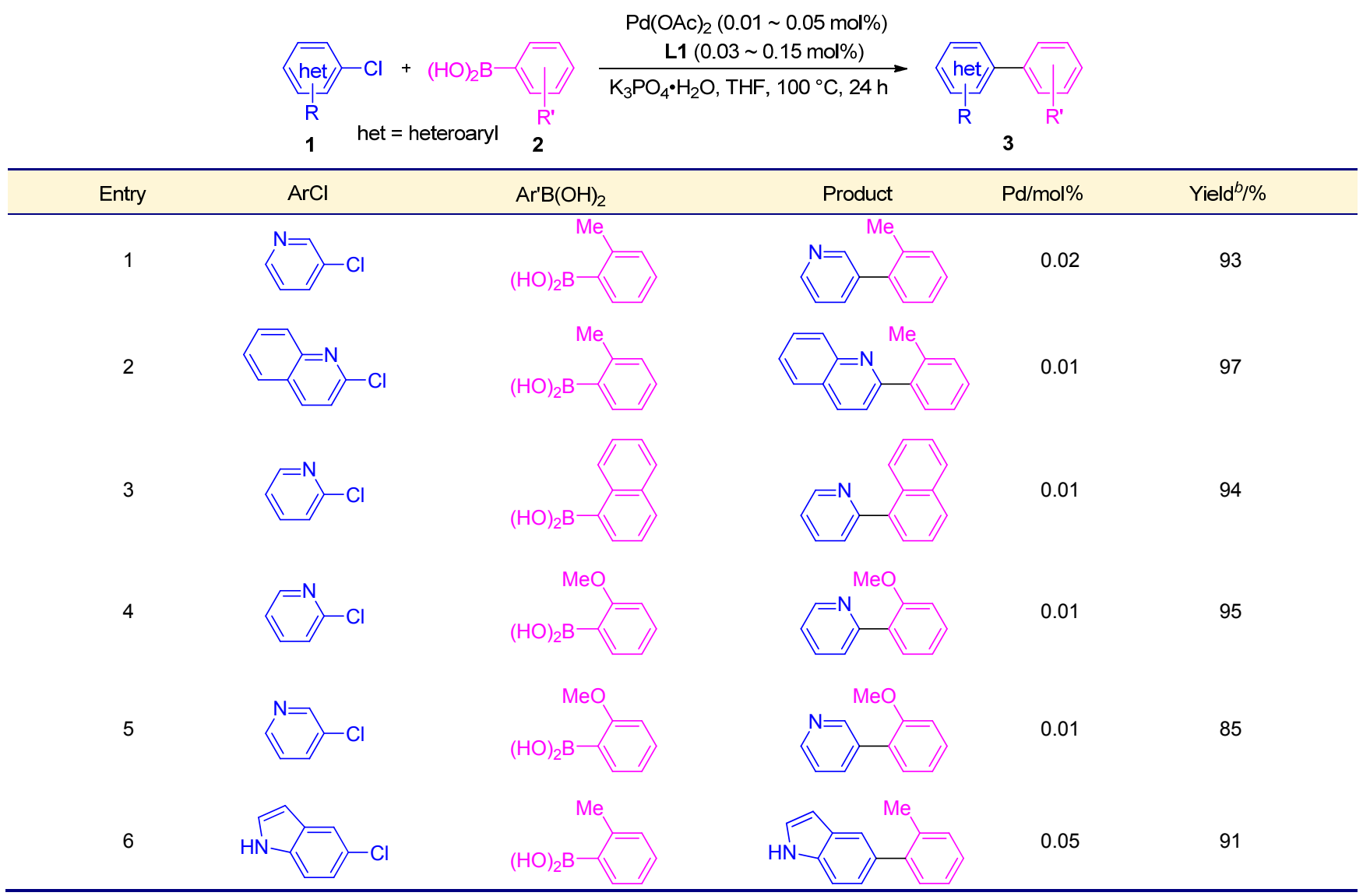

${ }^{a}$ Reaction conditions: heteroaryl chlorides $(1.0 \mathrm{mmol})$, arylboronic acid $(1.5 \mathrm{mmol})$, $\mathrm{Pd}: \mathbf{L 1}(1: 3), \mathrm{K}_{3} \mathrm{PO}_{4} \bullet \mathrm{H}_{2} \mathrm{O}(3 \mathrm{mmol})$, and THF $(3 \mathrm{~mL})$ were stirred at $100{ }^{\circ} \mathrm{C}$ for $24 \mathrm{~h}$ under $\mathrm{N}_{2} .{ }^{b}$ Isolated yields were reported. Reaction times were not optimized for each substrate. 
points were recorded on an uncorrected instrument. ${ }^{1} \mathrm{H}$ NMR spectra were recorded on a $400 \mathrm{MHz}$ spectrometer. Spectra were referenced internally to the residual proton resonance in $\mathrm{CDCl}_{3}(\delta 7.26)$ or to tetramethylsilane (TMS) $(\delta 0.00)$ as an internal standard. Chemical shifts $(\delta)$ were reported downfield from TMS. ${ }^{13} \mathrm{C}$ NMR spectra were recorded on a $100 \mathrm{MHz}$ spectrometer, and the spectra were referenced to $\mathrm{CDCl}_{3}\left(\delta 77.0\right.$, the middle peak). ${ }^{31} \mathrm{P} \mathrm{NMR}$ spectra were referenced to the external $85 \% \mathrm{H}_{3} \mathrm{PO}_{4}$. Mass spectrometry (EI-MS and ESI-MS) was performed on a mass spectrometer. High-resolution mass spectrometry (HRMS) was performed on a Q Exactive Focus Orbitrap mass spectrometer with an atmospheric-pressure chemical ionization (APCI) source. GC-MS analysis was conducted on a GCD system using a $30 \mathrm{~m} \times 0.25 \mathrm{~mm}$ HP-5MS column. Product GC yields were obtained on the basis of authentic sample/dodecane calibration standards from the GC-FID system.

\subsection{General procedures for the synthesis of ligands (L1 L7, $t$-Bu-L1, i-Pr-L1 and Ph-L1)}

2-(Dicyclohexylphosphino)- $N, N$-diisopropyl-5-methoxy- $1 H$-indole-1-carboxamide (L1): The synthetic conditions of $\mathbf{L 1}$ were slightly modified from the literature. ${ }^{[23 \mathrm{c}]}$ 5-Methoxy- $1 H$-indole ( $10 \mathrm{mmol}, 1.47 \mathrm{~g}$ ) was dissolved in anhydrous THF $(20 \mathrm{~mL})$ and added dropwise to the flask charged with THF $(100 \mathrm{~mL})$ solution with $\mathrm{NaH}(60 \%$ in mineral oil, $11 \mathrm{mmol}, 3.0 \mathrm{~g})$. The reaction was allowed to stir for $30 \mathrm{~min}$ at room temperature. After cooling to $0{ }^{\circ} \mathrm{C}$, $N, N$-diisopropylcarbamoyl chloride in THF $(20 \mathrm{~mL})$ was added dropwise and the reaction mixtures were allowed to stir for another $2 \mathrm{~h}$ at r.t. After the completion of the reaction as confirmed by GC-MS analysis, the reaction mixtures were cooled to $-78{ }^{\circ} \mathrm{C}$. $n$ - BuLi $(11 \mathrm{mmol})$ was added dropwise and the resulting mixtures were stirred for $1 \mathrm{~h}$. Then the chlorodicyclohexylphosphine was added dropwise and the reaction was allowed to reach room temperature and stirred overnight. $\mathrm{MeOH}(15 \mathrm{~mL})$ was added to quench the reaction. After the removing of solvent, dichloromethane (DCM) $(350 \mathrm{~mL})$ was added to the mixture, and washed by water $(150 \mathrm{~mL} \times 3)$ and brine $(150 \mathrm{~mL})$. The organic aliquot was dried with $\mathrm{MgSO}_{4}$ and then concentrated to a saturated solution. The cold $\mathrm{MeOH}$ was added and the precipitates were generated. Simple filtration was carried out to afford the desired product $\mathbf{L} \mathbf{1}$ as a white solid (3.55 g, 69\% yield). m.p. 142.3 142.9 ${ }^{\circ} \mathrm{C} ;{ }^{1} \mathrm{H}$ NMR $\left(400 \mathrm{MHz}, \mathrm{CDCl}_{3}\right) \delta: 1.24 \sim 1.92(\mathrm{~m}, 34 \mathrm{H}), 3.43 \sim$ $3.52(\mathrm{~m}, 2 \mathrm{H}), 3.87(\mathrm{~d}, J=10.7 \mathrm{~Hz}, 1 \mathrm{H}), 6.67(\mathrm{~s}, 1 \mathrm{H}), 6.89$ $(\mathrm{d}, \quad J=6.6 \mathrm{~Hz}, 1 \mathrm{H}), 7.08(\mathrm{~d}, J=2.2 \mathrm{~Hz}, 1 \mathrm{H}), 7.21(\mathrm{~d}, J=$ $8.8 \mathrm{~Hz}, 1 \mathrm{H}), 7.23(\mathrm{~s}, 1 \mathrm{H}) ;{ }^{13} \mathrm{C} \mathrm{NMR}\left(100 \mathrm{MHz}, \mathrm{CDCl}_{3}\right) \delta$ : 20.3, 20.5, 20.7, 20.8, 26.3, 26.5, 27.1, 27.2, 28.9, 29.0, $29.2,29.8,30.0,30.1,33.8,55.6,101.4,109.3,109.4$, $111.1,113.0,128.3,132.2,135.1,135.3,151.7,154.6$ (complex unresolved $\mathrm{C}-\mathrm{P}$ splitting was observed); ${ }^{31} \mathrm{P}$ NMR (202 MHz, $\left.\mathrm{CDCl}_{3}\right) \delta$ : -21.84 ; HRMS calcd for $\mathrm{C}_{28} \mathrm{H}_{44} \mathrm{~N}_{2} \mathrm{O}_{2} \mathrm{P}\left(\mathrm{M}+\mathrm{H}^{+}\right): 471.3140$, found 471.3150.

2-(Dicyclohexylphosphino)- $N, N$-diisopropyl-5-phenyl-
$1 H$-indole-1-carboxamide (L2): Followed the general procedure of synthesis of L1. 5-Phenyl-1 $H$-indole was used to obtain the desired product as a white solid (3.59 g, 64\% yield). m.p. $188.1 \sim 189.4{ }^{\circ} \mathrm{C} ;{ }^{1} \mathrm{H}$ NMR (400 MHz, $\left.\mathrm{CDCl}_{3}\right) \delta: 1.26 \sim 1.94(\mathrm{~m}, 34 \mathrm{H}), 3.20 \sim 3.60(\mathrm{~m}, 2 \mathrm{H}), 6.80$ $(\mathrm{s}, 1 \mathrm{H}), 7.33 \sim 7.39(\mathrm{~m}, 2 \mathrm{H}), 7.47(\mathrm{t}, J=6.3 \mathrm{~Hz}, 3 \mathrm{H}), 7.67$ $(\mathrm{d}, J=7.7 \mathrm{~Hz}, 2 \mathrm{H}), 7.83(\mathrm{~s}, 1 \mathrm{H}) ;{ }^{13} \mathrm{C} \mathrm{NMR}(100 \mathrm{MHz}$, $\left.\mathrm{CDCl}_{3}\right) \delta: 20.7,21.0,26.3,27.2,30.0,30.1,33.9,110.1$, $110.5,118.7,122.5,126.3,127.2,128.4,128.6,134.1$, 135.6, 135.8, 136.4, 142.2, 151.5 (complex unresolved $\mathrm{C}-\mathrm{P}$ splitting was observed); ${ }^{31} \mathrm{P} \mathrm{NMR}$ (202 $\mathrm{MHz}$, $\left.\mathrm{CDCl}_{3}\right) \delta$ : -21.90 ; HRMS calcd for $\mathrm{C}_{33} \mathrm{H}_{46} \mathrm{~N}_{2} \mathrm{OP}(\mathrm{M}+$ $\mathrm{H}^{+}$): 517.3348 , found 517.3355 .

2-(Dicyclohexylphosphino)-5-fluoro- $N, N$-diisopropyl$1 H$-indole-1-carboxamide (L3): Followed the general procedure of synthesis of L1. 5-Fluoro-1 $H$-indole was used to obtain the desired product as a white solid (2.82 g, 56\% yield). m.p. $157.3 \sim 159.4{ }^{\circ} \mathrm{C} ;{ }^{1} \mathrm{H}$ NMR $(400 \mathrm{MHz}$, $\left.\mathrm{CDCl}_{3}\right) \delta: 1.24 \sim 1.92(\mathrm{~m}, 34 \mathrm{H}), 3.42(\mathrm{bs}, 2 \mathrm{H}), 6.70(\mathrm{~s}$, $1 \mathrm{H}), 6.95 \sim 7.00(\mathrm{~m}, 1 \mathrm{H}), 7.21 \sim 7.28(\mathrm{~m}, 2 \mathrm{H}) ;{ }^{13} \mathrm{C} \mathrm{NMR}$ $\left(100 \mathrm{MHz}, \mathrm{CDCl}_{3}\right) \delta: 20.5,21.0,26.2,27.1,29.9,30.0$, $30.1,33.7,104.8,105.0,105.1,109.4,109.5,110.7,110.9$, $111.0,128.1,128.2,133.4,133.5,136.7,136.9,151.3$, 157.0, 159.3 (complex unresolved $\mathrm{C}-\mathrm{P}$ splitting was observed); ${ }^{31} \mathrm{P}$ NMR (202 $\left.\mathrm{MHz}, \mathrm{CDCl}_{3}\right) \delta$ : -21.56 ; HRMS calcd For $\mathrm{C}_{27} \mathrm{H}_{41} \mathrm{~N}_{2} \mathrm{OFP}\left(\mathrm{M}+\mathrm{H}^{+}\right)$: 459.2941, found 459.2956 .

5-Chloro-2-(dicyclohexylphosphino)- $N, N$-diisopropyl$1 H$-indole-1-carboxamide (L4): Followed by the procedure of synthesis of L1. 5-Chloro-1H-indole was used to obtain the desired product as a white solid (4.11 g, 79\% yield). m.p. $169.1 \sim 171.7{ }^{\circ} \mathrm{C} ;{ }^{1} \mathrm{H}$ NMR $\left(400 \mathrm{MHz}, \mathrm{CDCl}_{3}\right) \delta$ : $1.24 \sim 1.99(\mathrm{~m}, 34 \mathrm{H}), 3.46 \sim 3.51(\mathrm{~m}, 2 \mathrm{H}), 6.68(\mathrm{~s}, 1 \mathrm{H})$, $7.15 \sim 7.30(\mathrm{~m}, 2 \mathrm{H}), 7.59 \sim 7.64(\mathrm{~m}, 1 \mathrm{H}) ;{ }^{13} \mathrm{C}$ NMR $(100$ $\left.\mathrm{MHz}, \mathrm{CDCl}_{3}\right) \delta: 20.6,21.1,26.2,27.1,29.9,30.0,33.7$, $109.0,111.1,119.6,122.7,126.0,128.8,135.1,136.5$, 136.7, 151.0 (complex unresolved $\mathrm{C}-\mathrm{P}$ splitting was observed); ${ }^{31} \mathrm{P}$ NMR (202 MHz, $\mathrm{CDCl}_{3}$ ) $\delta$ : -21.64; HRMS calcd for $\mathrm{C}_{27} \mathrm{H}_{41} \mathrm{~N}_{2} \mathrm{OClP}\left(\mathrm{M}+\mathrm{H}^{+}\right)$: 475.2645, found 459.2651.

2-(Dicyclohexylphosphino)- $N, N$-diisopropyl-5-(trifluoromethyl)-1 $H$-indole-1-carboxamide (L5): Followed the general procedure of synthesis of L1. 5-(Trifluoromethyl)$1 \mathrm{H}$-indole was used to obtain the desired product as a white solid (2.75 g, 50\% yield). m.p. 191.1 192.5 ${ }^{\circ} \mathrm{C} ;{ }^{1} \mathrm{H}$ NMR $\left(400 \mathrm{MHz}, \mathrm{CDCl}_{3}\right) \delta: 0.91 \sim 2.20(\mathrm{~m}, 34 \mathrm{H}), 3.31 \sim$ $3.61(\mathrm{~m}, 2 \mathrm{H}), 6.85(\mathrm{~s}, 1 \mathrm{H}), 7.39 \sim 7.48(\mathrm{~m}, 2 \mathrm{H}), 7.95(\mathrm{~s}$, $1 \mathrm{H}) ;{ }^{13} \mathrm{C} \mathrm{NMR}\left(100 \mathrm{MHz}, \mathrm{CDCl}_{3}\right) \delta: 20.3,20.7,20.8,21.0$, $26.2,26.5,26.8,27.2,27.3,27.4,28.9,29.0,30.1,30.2$, $30.4,33.7,110.3,110.5,118.1,118.2,119.1,122.7,123.0$, 123.8, 126.5, 127.2, 137.4, 137.6, 138.0, 150.8 (complex unresolved $\mathrm{C}-\mathrm{P}$ splitting was observed); ${ }^{31} \mathrm{P}$ NMR (202 $\left.\mathrm{MHz}, \mathrm{CDCl}_{3}\right) \delta$ : -21.79 ; HRMS calcd for $\mathrm{C}_{28} \mathrm{H}_{41} \mathrm{~N}_{2} \mathrm{O}$ $\mathrm{F}_{3} \mathrm{P}\left(\mathrm{M}+\mathrm{H}^{+}\right): 509.2909$, found 509.2914.

2-(Dicyclohexylphosphino)- $N, N$-diisopropyl-5-methyl$1 \mathrm{H}$-indole-1-carboxamide (L6): Followed the general procedure of synthesis of L1. 5-Methyl-1 $H$-indole was used to 
obtain the desired product as a white solid (3.34 g, 67\% yield). m.p. $162.3 \sim 163.1{ }^{\circ} \mathrm{C} ;{ }^{1} \mathrm{H}$ NMR $(400 \mathrm{MHz}$, $\left.\mathrm{CDCl}_{3}\right) \delta: 1.44 \sim 1.76(\mathrm{~m}, 30 \mathrm{H}), 1.80 \sim 2.05(\mathrm{~m}, 2 \mathrm{H})$, $2.31 \sim 2.33(\mathrm{~m}, 2 \mathrm{H}), 2.47(\mathrm{~s}, 3 \mathrm{H}), 3.48 \sim 3.53(\mathrm{~m}, 2 \mathrm{H})$, 6.69 (s, 1H), 7.04 (d, $J=9.0 \mathrm{~Hz}, 1 \mathrm{H}), 7.22$ (d, $J=8.4 \mathrm{~Hz}$, $1 \mathrm{H}), 7.40(\mathrm{~s}, 1 \mathrm{H}) ;{ }^{13} \mathrm{C} \mathrm{NMR}\left(100 \mathrm{MHz}, \mathrm{CDCl}_{3}\right) \delta: 20.5$, 20.8, 21.2, 21.3, 25.6, 26.0, 26.3, 26.4, 26.7, 30.6, 30.8, $37.1,37.4,37.5,37.8,48.5,48.7,108.7,108.8,110.0$, $119.8,119.9,120.2,124.1,128.2$, 129.6, 135.0, 135.1, 137.5, 137.7, 151.8 (complex unresolved $\mathrm{C}-\mathrm{P}$ splitting was observed); ${ }^{31} \mathrm{P} \mathrm{NMR}\left(202 \mathrm{MHz}, \mathrm{CDCl}_{3}\right) \delta$ : -25.20 ; HRMS calcd for $\mathrm{C}_{28} \mathrm{H}_{44} \mathrm{~N}_{2} \mathrm{OP}\left(\mathrm{M}+\mathrm{H}^{+}\right)$: 455.3191, found 455.3208 .

2-(Di-tert-butylphosphino)- $N, N$-diisopropyl-5-methoxy$1 H$-indole-1-carboxamide ( $t$-Bu-L1): Followed the general procedure of synthesis of L1. Di-tert-butylchlorophosphine was used to obtain the desired product as a white solid (3.29 g, 71\% yield). m.p. 128.6 129.7 ${ }^{\circ} \mathrm{C} ;{ }^{1} \mathrm{H}$ NMR $\left(400 \mathrm{MHz}, \mathrm{CDCl}_{3}\right) \delta: 1.11 \sim 1.70(\mathrm{~m}, 30 \mathrm{H}), 3.60 \sim 3.75$ $(\mathrm{m}, 2 \mathrm{H}), 3.87(\mathrm{~s}, 3 \mathrm{H}), 6.87 \sim 6.95(\mathrm{~m}, 2 \mathrm{H}), 7.08(\mathrm{~d}, J=2.5$ $\mathrm{Hz}, 1 \mathrm{H}), 7.18 \sim 7.22(\mathrm{~m}, 1 \mathrm{H}) ;{ }^{13} \mathrm{C}$ NMR $(100 \mathrm{MHz}$, $\left.\mathrm{CDCl}_{3}\right) \delta: 20.8,21.2,30.5,30.6,32.8,33.0,48.5,55.6$, $101.6,102.7,104.5,111.3,111.7,112.9,113.3,113.6$, $125.7,128.6,129.5,130.9,132.2,132.3,136.0,136.2$, 151.2, 154.6, 155.1 (complex unresolved $\mathrm{C}-\mathrm{P}$ splitting was observed); ${ }^{31} \mathrm{P}$ NMR (202 $\left.\mathrm{MHz}, \mathrm{CDCl}_{3}\right) \quad \delta$ : 9.43; HRMS calcd for $\mathrm{C}_{24} \mathrm{H}_{40} \mathrm{~N}_{2} \mathrm{O}_{2} \mathrm{P}\left(\mathrm{M}+\mathrm{H}^{+}\right): 419.2827$, found 419.2840 .

2-(Diisopropylphosphino)- $N, N$-diisopropyl-5-methoxy-1 $H$-indole-1-carboxamide ( $i$-Pr-L1): Followed the general procedure of synthesis of L1. Chlorodiisopropylphosphine was used to obtain the desired product as a white solid (3.26 g, 75\% yield). m.p. 110.1 111.8 ${ }^{\circ} \mathrm{C} ;{ }^{1} \mathrm{H}$ NMR (400 $\left.\mathrm{MHz}, \mathrm{CDCl}_{3}\right) \delta: 1.11 \sim 1.60(\mathrm{~m}, 26 \mathrm{H}), 2.18(\mathrm{~s}, 2 \mathrm{H}), 3.45 \sim$ $3.51(\mathrm{~m}, 2 \mathrm{H}), 3.87(\mathrm{~s}, 3 \mathrm{H}), 6.67(\mathrm{~d}, J=0.4 \mathrm{~Hz}, 1 \mathrm{H}), 6.87 \sim$ $6.90(\mathrm{~m}, 1 \mathrm{H}), 7.06(\mathrm{~d}, J=2.4 \mathrm{~Hz}, 1 \mathrm{H}), 7.21(\mathrm{~d}, J=8.8 \mathrm{~Hz}$, $1 \mathrm{H}) ;{ }^{13} \mathrm{C}$ NMR $\left(100 \mathrm{MHz}, \mathrm{CDCl}_{3}\right) \delta: 19.7,19.9,20.6,24.1$, $55.7,101.6,109.3,109.4,111.1,113.2,128.3,132.2$, 132.3, 135.4, 135.6, 151.2, 154.6 (complex unresolved $\mathrm{C}-\mathrm{P}$ splitting was observed); ${ }^{31} \mathrm{P} \mathrm{NMR}(202 \mathrm{MHz}$, $\left.\mathrm{CDCl}_{3}\right) \delta$ : -13.36 ; HRMS calcd for $\mathrm{C}_{22} \mathrm{H}_{36} \mathrm{~N}_{2} \mathrm{O}_{2} \mathrm{P}(\mathrm{M}+$ $\left.\mathrm{H}^{+}\right)$: 391.2514, found 391.2499.

2-(Diphenylphosphino)- $N, N$-diisopropyl-5-methoxy- $1 H$ indole-1-carboxamide (Ph-L1) Followed by the procedure of synthesis of $\mathbf{L 1}$. Chlorodiphenylphosphine was used to obtain a desired product as white solid (3.27 g, 65\% yield). m.p. $186.1 \sim 187.4{ }^{\circ} \mathrm{C} ;{ }^{1} \mathrm{H}$ NMR $\left(400 \mathrm{MHz}, \mathrm{CDCl}_{3}\right) \delta$ : $1.34(\mathrm{~d}, J=6.4 \mathrm{~Hz}, 12 \mathrm{H}), 3.50 \sim 3.57(\mathrm{~m}, 2 \mathrm{H}), 3.83(\mathrm{~s}$, $3 \mathrm{H}), 6.23(\mathrm{~s}, 1 \mathrm{H}), 6.89 \sim 6.91(\mathrm{~m}, 1 \mathrm{H}), 6.97(\mathrm{~d}, J=2.4 \mathrm{~Hz}$, $1 \mathrm{H}), 7.23(\mathrm{~d}, J=8.8 \mathrm{~Hz}, 1 \mathrm{H}), 7.34 \sim 7.45(\mathrm{~m}, 10 \mathrm{H}) ;{ }^{13} \mathrm{C}$ NMR $\left(100 \mathrm{MHz}, \mathrm{CDCl}_{3}\right) \delta: 20.6,20.7,21.2,48.5,48.8$, 55.6, 55.7, 102.0, 111.3, 112.4, 113.6, 125.7, 128.3, 128.4, $128.5,128.8,133.1,133.2,133.4,133.6,135.9,136.0$, 136.7, 136.8, 151.2, 154.8 (complex unresolved $\mathrm{C}-\mathrm{P}$ splitting was observed); ${ }^{31} \mathrm{P}$ NMR $\left(202 \mathrm{MHz}, \mathrm{CDCl}_{3}\right) \delta$ : - 27.76; HRMS calcd for $\mathrm{C}_{28} \mathrm{H}_{32} \mathrm{~N}_{2} \mathrm{O}_{2} \mathrm{P}\left(\mathrm{M}+\mathrm{H}^{+}\right)$: 459.2201, found 459.2216.
4.3 General procedures for Pd-catalyzed SuzukiMiyaura coupling of $\mathrm{ArCl}$

$\mathrm{Pd}(\mathrm{OAc})_{2}(2.3 \mathrm{mg}, 0.010 \mathrm{mmol})$ and ligand $(0.030$ mmol) were loaded into an oven-dried Schlenk tube equipped with a Teflon-coated magnetic stir bar. The tube was evacuated and flushed with nitrogen for three cycles. Precomplexation was applied by adding freshly distilled THF into the tube for stirring about 1 to 2 min until all the metal and ligand were dissolved in the solvent. Aryl chloride $(1.0 \mathrm{mmol})$, arylboronic acid $(1.5 \mathrm{mmol})$, and $\mathrm{K}_{3} \mathrm{PO}_{4}{ }^{\bullet}$ $\mathrm{H}_{2} \mathrm{O}(3.0 \mathrm{mmol})$ were loaded into another Schlenk tube, and the system was further evacuated and flushed with nitrogen for three times. The corresponding amount of precomplexation solution was added, following by the addition of THF to final volume of $3 \mathrm{~mL}$. The tube was stirred at room temperature for $5 \mathrm{~min}$ and then placed into a preheated oil bath $\left(100{ }^{\circ} \mathrm{C}\right)$ for $24 \mathrm{~h}$. After the completion of reaction, the reaction tube was allowed to cool to room temperature and quenched with water and diluted with EtOAc. The organic layer was separated and the aqueous layer was washed with diethyl ether twice. The combined organic layer was concentrated under reduced pressure. The crude products were purified by flash column chromatography on silica gel $(230 \sim 400$ mesh $)$ to afford the desired product.

\subsection{Characterization data of coupling reaction pro- ducts}

2,4',6-Trimethyl-1,1'-biphenyl (3aa; Table 1, Entry 1) ${ }^{[29]}$ $R_{\mathrm{f}}=0.5$ (pure hexane); ${ }^{1} \mathrm{H}$ NMR $\left(400 \mathrm{MHz}, \mathrm{CDCl}_{3}\right) \delta: 2.10$ (s, 6H), 2.47 (s, 3H), 7.09 (d, $J=8.0 \mathrm{~Hz}, 2 \mathrm{H}), 7.15 \sim 7.19$ $(\mathrm{m}, 3 \mathrm{H}), 7.29(\mathrm{~d}, J=8.0 \mathrm{~Hz}, 2 \mathrm{H}) ;{ }^{13} \mathrm{C} \mathrm{NMR}(100 \mathrm{MHz}$, $\left.\mathrm{CDCl}_{3}\right) \delta: 20.8,20.8,21.2,21.2,126.9,127.2,128.8$, $129.1,135.9,136.1,138.0,141.8$.

2-Methoxy-2'-methyl-1,1'-biphenyl (Table 1, Entries 2 and 3$){ }^{\left[{ }^{30]}\right.} R_{\mathrm{f}}=0.3$ (EtOAc/Hexane, $\left.V: V=1: 50\right) ;{ }^{1} \mathrm{H}$ NMR (400 MHz, $\left.\mathrm{CDCl}_{3}\right) \delta: 2.23(\mathrm{~s}, 3 \mathrm{H}), 3.84(\mathrm{~s}, 3 \mathrm{H})$, $7.04 \sim 7.12(\mathrm{~m}, 2 \mathrm{H}), 7.23 \sim 7.35(\mathrm{~m}, 5 \mathrm{H}), 7.41 \sim 7.43(\mathrm{~m}$, $1 \mathrm{H}) ;{ }^{13} \mathrm{C} \mathrm{NMR}\left(100 \mathrm{MHz}, \mathrm{CDCl}_{3}\right) \delta: 19.8,19.8,55.2$, $110.6,120.4,125.3,127.2,128.5,129.5,129.9,130.8$, $130.9,136.7,138.6,156.5$.

4'-Methoxy-2-methyl-1,1'-biphenyl (Table 1, Entry 4): ${ }^{[31]} R_{\mathrm{f}}=0.2$ (EtOAc/Hexane, $\left.V: V=1: 50\right) ;{ }^{1} \mathrm{H}$ NMR $\left(400 \mathrm{MHz}, \mathrm{CDCl}_{3}\right) \delta: 2.38(\mathrm{~s}, 3 \mathrm{H}), 3.88(\mathrm{~s}, 3 \mathrm{H}), 7.05(\mathrm{~d}$, $J=9.2 \mathrm{~Hz}, 2 \mathrm{H}), 7.32 \sim 7.36(\mathrm{~m}, 6 \mathrm{H}) ;{ }^{13} \mathrm{C} \mathrm{NMR}(100 \mathrm{MHz}$, $\left.\mathrm{CDCl}_{3}\right) \delta: 20.5,55.2,113.5,125.7,127.0,129.9,130.2$, $130.3,134.4,135.5,141.6,158.3$.

$\left[1,1\right.$ '-Biphenyl]-3-carbonitrile (Table 1, Entry 5): ${ }^{[32]} R_{\mathrm{f}}=$ 0.4 (EtOAc/Hexane, $V: V=1: 50) ;{ }^{1} \mathrm{H}$ NMR $(400 \mathrm{MHz}$, $\left.\mathrm{CDCl}_{3}\right) \delta: 7.31 \sim 7.53(\mathrm{~m}, 6 \mathrm{H}), 7.67 \sim 7.71(\mathrm{~m}, 1 \mathrm{H}), 7.74$ $(\mathrm{m}, 2 \mathrm{H}) ;{ }^{13} \mathrm{C}$ NMR $\left(100 \mathrm{MHz}, \mathrm{CDCl}_{3}\right) \delta: 112.8,118.6$, $126.9,128.3,129.0,129.5,130.5,130.5,131.9$, 138.7, 142.3 .

1-(3',5'-Dimethyl-[1,1'-biphenyl]-3-yl)ethan-1-one (Table 1, Entry 6): ${ }^{[23 \mathrm{c}]} R_{\mathrm{f}}=0.3$ (pure hexane); ${ }^{1} \mathrm{H}$ NMR (400 $\left.\mathrm{MHz}, \mathrm{CDCl}_{3}\right) \delta: 2.41(\mathrm{~s}, 6 \mathrm{H}), 2.67(\mathrm{~s}, 3 \mathrm{H}), 7.05(\mathrm{~s}, 1 \mathrm{H})$, 7.25 (s, 2H), 7.52 (d, $J=12.4 \mathrm{~Hz}, 1 \mathrm{H}), 7.79$ (d, $J=8.4 \mathrm{~Hz}$, 
$1 \mathrm{H}), 7.93$ (d, $J=8.4 \mathrm{~Hz}, 1 \mathrm{H}), 8.20$ (s, 1H); ${ }^{13} \mathrm{C}$ NMR $(100$ $\left.\mathrm{MHz}, \mathrm{CDCl}_{3}\right) \delta: 21.2,26.6,124.4,126.8,126.9,128.8$, 129.3, 131.6, 137.4, 138.9, 140.0, 141.8, 198.0.

1-(2'-Methoxy-[1,1'-biphenyl]-4-yl)ethan-1-one (Table 1, Entry 7): ${ }^{[33]} R_{\mathrm{f}}=0.5$ (EtOAc/Hexane, $\left.V: V=1: 9\right) ;{ }^{1} \mathrm{H}$ NMR (400 MHz, $\left.\mathrm{CDCl}_{3}\right) \delta: 2.61(\mathrm{~s}, 3 \mathrm{H}), 3.80(\mathrm{~s}, 3 \mathrm{H})$, $6.97 \sim 7.03(\mathrm{~m}, 2 \mathrm{H}), 7.30 \sim 7.34(\mathrm{~m}, 2 \mathrm{H}), 7.62(\mathrm{~d}, J=4.0$ $\mathrm{Hz}, 2 \mathrm{H}), 7.98$ (d, $J=6.4 \mathrm{~Hz}) ;{ }^{13} \mathrm{C}$ NMR $\left(100 \mathrm{MHz}, \mathrm{CDCl}_{3}\right)$ $\delta: 26.5,55.5,111.3,120.9,128.0,129.4,129.4,130.6$, 135.4, 143.5, 156.4, 197.7.

2'-Methyl-[1,1'-biphenyl]-4-carbaldehyde (Table 1, Entry 8$)^{[23 \mathrm{c}]} R_{\mathrm{f}}=0.5($ EtOAc/Hexane, $V: V=1: 9) ;{ }^{1} \mathrm{H}$ NMR $\left(400 \mathrm{MHz}, \mathrm{CDCl}_{3}\right) \delta: 2.30(\mathrm{~s}, 3 \mathrm{H}), 7.24 \sim 7.31(\mathrm{~m}, 4 \mathrm{H})$, 7.50 (d, $J=6.4 \mathrm{~Hz}, 2 \mathrm{H}), 7.94$ (d, $J=6.4 \mathrm{~Hz}, 2 \mathrm{H}), 10.07$ (s, $1 \mathrm{H}) ;{ }^{13} \mathrm{C} \mathrm{NMR}\left(100 \mathrm{MHz}, \mathrm{CDCl}_{3}\right) \delta: 20.2,125.1,127.3$, $129.3,129.4,129.8,130.5,134.5,134.9,140.4,148.2$, 191.8 .

Methyl 2'-methyl-[1,1'-biphenyl]-3-carboxylate (Table 1, Entry 9): ${ }^{[17]} R_{\mathrm{f}}=0.3$ (pure hexane); ${ }^{1} \mathrm{H}$ NMR $(400 \mathrm{MHz}$, $\left.\mathrm{CDCl}_{3}\right) \delta: 2.30(\mathrm{~s}, 3 \mathrm{H}), 3.97(\mathrm{~s}, 3 \mathrm{H}), 7.24 \sim 7.31(\mathrm{~m}, 4 \mathrm{H})$, $7.43(\mathrm{~d}, J=8.2 \mathrm{~Hz}, 2 \mathrm{H}), 8.14(\mathrm{~d}, J=8.2 \mathrm{~Hz}, 2 \mathrm{H}) ;{ }^{13} \mathrm{C} \mathrm{NMR}$ $\left(100 \mathrm{MHz}, \mathrm{CDCl}_{3}\right) \delta: 20.6,52.3,126.1,127.3,128.3$, $128.4,129.5,129.5,130.4,130.5,130.6,133.9,135.5$, $141.1,142.5,167.3$.

3-(o-Tolyl)pyridine (Table 2, Entry 1): ${ }^{[23 \mathrm{c}]} R_{\mathrm{f}}=0.4$ (EtOAc/Hexane, $V: V=1: 9) ;{ }^{1} \mathrm{H}$ NMR $(400 \mathrm{MHz}$, $\left.\mathrm{CDCl}_{3}\right) \delta: 2.27(\mathrm{~s}, 3 \mathrm{H}), 7.22 \sim 7.30(\mathrm{~m}, 5 \mathrm{H}), 7.58(\mathrm{~d}, J=$ $7.8 \mathrm{~Hz}, 1 \mathrm{H}), 8.54 \sim 8.57(\mathrm{~m}, 2 \mathrm{H}) ;{ }^{13} \mathrm{C}$ NMR $(100 \mathrm{MHz}$, $\left.\mathrm{CDCl}_{3}\right) \delta: 20.2,122.9,126.0,128.6,129.7,130.5,135.4$, 136.3, 137.4, 138.0, 148.0, 149.6.

2-(o-Tolyl)quinoline (Table 2, Entry 2$):{ }^{[23 \mathrm{c}]} R_{\mathrm{f}}=0.5$ (EtOAc/Hexane, $V: V=1: 9) ;{ }^{1} \mathrm{H}$ NMR $(400 \mathrm{MHz}$, $\left.\mathrm{CDCl}_{3}\right) \delta: 2.57(\mathrm{~s}, 3 \mathrm{H}), 7.81 \sim 7.98(\mathrm{~m}, 5 \mathrm{H}), 8.14 \sim 8.15$ $(\mathrm{m}, 2 \mathrm{H}), 8.17$ (d, $J=8.4 \mathrm{~Hz}, 1 \mathrm{H}), 8.37(\mathrm{~d}, J=6.4 \mathrm{~Hz}, 1 \mathrm{H})$, $9.12(\mathrm{~d}, J=4.0 \mathrm{~Hz}, 1 \mathrm{H}) ;{ }^{13} \mathrm{C} \mathrm{NMR}\left(100 \mathrm{MHz}, \mathrm{CDCl}_{3}\right) \delta$ : $19.3,119.4,125.1,126.3,126.7,126.8,127.9,129.0$, $129.5,129.8,135.8,135.8,138.5,141.6,160.8$.

2-(Naphthalen-1-yl)pyridine (Table 2, Entry 3): ${ }^{[34]} R_{\mathrm{f}}=$ 0.3 (pure hexane); ${ }^{1} \mathrm{H} \mathrm{NMR}\left(400 \mathrm{MHz}, \mathrm{CDCl}_{3}\right) \delta: 7.51(\mathrm{~m}$, $1 \mathrm{H}), 7.52 \sim 7.57(\mathrm{~m}, 6 \mathrm{H}), 7.57 \sim 7.65(\mathrm{~m}, 2 \mathrm{H}), 7.75(\mathrm{~m}$, 1H), $7.92 \sim 7.94(\mathrm{~m}, 1 \mathrm{H}) ;{ }^{13} \mathrm{C}$ NMR $\left(100 \mathrm{MHz}, \mathrm{CDCl}_{3}\right) \delta$ : $121.7,124.8,125.0,125.4,125.6,126.2,127.2,128.1$, $128.6,130.9,133.7,136.1,138.3,149.2,159.0$.

2-(2-Methoxyphenyl)pyridine (Table 2, Entry 4) ${ }^{[35]} R_{\mathrm{f}}=$ 0.4 (EtOAc/Hexane, $V: V=1: 9) ;{ }^{1} \mathrm{H}$ NMR $(400 \mathrm{MHz}$, $\left.\mathrm{CDCl}_{3}\right) \delta: 3.81(\mathrm{~s}, 3 \mathrm{H}), 6.97 \sim 7.17(\mathrm{~m}, 1 \mathrm{H}), 7.33 \sim 7.37$ $(\mathrm{m}, 1 \mathrm{H}), 7.64 \sim 7.67(\mathrm{~m}, 1 \mathrm{H}), 7.78 \sim 7.82(\mathrm{~m}, 1 \mathrm{H}), 8.69 \sim$ $8.70(\mathrm{~m}, 3 \mathrm{H}), 8.70(\mathrm{~d}, J=1.2 \mathrm{~Hz}, 1 \mathrm{H}) ;{ }^{13} \mathrm{C} \mathrm{NMR}(100$ $\left.\mathrm{MHz}, \mathrm{CDCl}_{3}\right) \delta: 55.3,111.2,120.8,121.4,124.9,128.7$, $130.9,135.3,149.2$.

3-(2-Methoxyphenyl)pyridine (Table 2, Entry 5): ${ }^{[36]}$ $R_{\mathrm{f}}=0.4($ EtOAc/Hexane, $V: V=1: 9) ;{ }^{1} \mathrm{H} \mathrm{NMR}(400$ $\left.\mathrm{MHz}, \mathrm{CDCl}_{3}\right) \delta: 3.81(\mathrm{~s}, 3 \mathrm{H}), 6.97 \sim 7.17(\mathrm{~m}, 4 \mathrm{H}), 7.33 \sim$ $7.36(\mathrm{~m}, 1 \mathrm{H}), 7.64 \sim 7.67(\mathrm{~m}, 1 \mathrm{H}), 7.78 \sim 7.82(\mathrm{~m}, 1 \mathrm{H})$, $8.64 \sim 8.70(\mathrm{~m}, 1 \mathrm{H}) ;{ }^{13} \mathrm{C} \mathrm{NMR}\left(100 \mathrm{MHz}, \mathrm{CDCl}_{3}\right) \delta: 55.3$, $111.2,120.8,121.4,124.9,128.3,129.7,130.5,135.3$, $143.1,155.9,156.7$.
5-(o-Tolyl)-1H-indole (Table 2, Entry 6): ${ }^{[9 \mathrm{~b}]} R_{\mathrm{f}}=0.3$ (EtOAc/Hexane, $V: V=1: 9) ;{ }^{1} \mathrm{H}$ NMR $(400 \mathrm{MHz}$, $\left.\mathrm{CDCl}_{3}\right) \delta: 2.34(\mathrm{~s}, 3 \mathrm{H}), 6.61 \sim 6.62(\mathrm{~m}, 1 \mathrm{H}), 7.16 \sim 7.29$ $(\mathrm{m}, 2 \mathrm{H}), 7.29 \sim 7.35(\mathrm{~m}, 5 \mathrm{H}), 7.43 \sim 7.62(\mathrm{~m}, 1 \mathrm{H}), 8.35$ (bs, $J=8.2 \mathrm{~Hz}, 1 \mathrm{H}) ;{ }^{13} \mathrm{C} \mathrm{NMR}\left(100 \mathrm{MHz}, \mathrm{CDCl}_{3}\right) \delta: 20.6$, $29.7,102.4,102.8,110.4,111.9,120.1,121.1,122.3$, $129.8,124.6,125.5,125.6,126.7,127.8,130.1,130.3$, $133.6,134.8,135.7,143.1$.

Supporting Information ${ }^{1} \mathrm{H}$ NMR, ${ }^{13} \mathrm{C}$ NMR original spectra of the target compounds and the X-ray crystallographic analysis of ligand $\mathbf{L 1} \sim \mathbf{L 7}$. The Supporting Information is available free of charge via the Internet at http://sioc- journal.cn/.

\section{References}

[1] For selected books, see:

(a) Negishi, E. Handbook of Organopalladium Chemistry for Organic Synthesis, Vols. 1 2, Wiley-Interscience, New York, 2002.

(b) de Meijere, A.; Diederich, F. Metal-Catalyzed Cross-Coupling Reactions, Vols. 1 2, Wiley-VCH, Weinheim, 2004.

(c) Ackermann, L. Modern Arylation Methods, Wiley-VCH, Weinheim, 2009.

For selected reviews, see:

(d) Corbet, J.-P.; Mignani, G. Chem. Rev. 2006, 106, 2651.

(e) Johansson Seechurn, C. C. C.; Kitching, M. O.; Colacot, T. J.; Snieckus, V. Angew. Chem., Int. Ed. 2012, 51, 5062.

(f) Biffis, A.; Centomo, P.; Del Zotto, A.; Zecca, M. Chem. Rev. 2018, 118, 2249.

(g) Zhang, Y.-F.; Shi, Z.-J. Acc. Chem. Res. 2019, 52, 161.

[2] (a) Magano, J.; Dunetz, J. R. Chem. Rev. 2011, 111, 2177.

(b) Biteau, N.; Hervin, V.; Roy, V.; Agrofoglio, L. A. In Palladium-Catalyzed Modification of Nucleosides, Nucleotides and Oligonucleotides, Vol. 1, Eds.: Kapdi, A. R.; Maiti, D.; Sanghvi, Y. S., Elsevier, Amsterdam, Netherlands, 2018, p. 37.

(c) Devendar, P.; Qu, R.-Y.; Kang, W.-M.; He, B.; Yang, G.-F. J. Agric. Food Chem. 2018, 66, 8914.

[3] For selected book, see:

(a) Stradiotto, M.; Lundgren, R. J. Ligand Design in Metal Chemistry, John Wiley \& Sons, Hoboken, NJ, 2016.

For selected articles, see:

(b) Valente, C.; Calimsiz, S.; Hoi, K. H.; Mallik, D.; Sayah, M.; Organ, M. G. Angew. Chem., Int. Ed. 2012, 51, 3314.

(c) Izquierdo, F.; Manzini, S.; Nolan, S. P. Chem. Commun. 2014, 50, 14926.

(d) Wong, S. M.; Yuen, O. Y.; Choy, P. Y.; Kwong, F. Y. Coord. Chem. Rev. 2015, 293-294, 158.

(e) Li, C.; Chen, D.; Tang, W. Synlett 2016, 2183.

[4] Fu, G. C. Acc. Chem. Res. 2008, 41, 1555.

[5] Hartwig, J. F. Synlett 1997, 329.

[6] (a) Surry, D. S.; Buchwald, S. L. Angew. Chem., Int. Ed. 2008, 47 , 6338.

(b) Martin, R.; Buchwald, S. L. Acc. Chem. Res. 2008, 41, 1461

[7] Ackermann, L.; Potukuchi, H. K.; Althammer, A.; Born, R.; Mayer, P. Org. Lett. 2010, 12, 1004.

[8] Zapf, A.; Beller, M. Chem. Commun. 2005, 431.

[9] (a) So, C. M.; Lau, C. P.; Kwong, F. Y. Angew. Chem., Int. Ed. 2008, 47, 8059 .

(b) So, C. M.; Chow, W. K.; Choy, P. Y.; Lau, C. P.; Kwong, F. Y. Chem.-Eur. J. 2010, 16, 7996.

[10] Lundgren, R. J.; Hesp, K. D.; Stradiotto, M. Synlett 2011, 2443.

[11] (a) Tang, W.; Capacci, A. G.; Wei, X.; Li, W.; White, A.; Patel, N. D.; Savoie, J.; Gao, J. J.; Rodriguez, S.; Qu, B.; Haddad, N.; Lu, B. 
Z.; Krishnamurthy, D.; Yee, N. K.; Senanayake, C. H. Angew. Chem., Int. Ed. 2010, 49, 5879.

(b) Zhao, Q.; Li, C.; Senanayake, C. H.; Tang, W. Chem.-Eur. J. 2013, 19, 2261

[12] Liu, D.; Gao, W.; Dai, Q.; Zhang, X. Org. Lett. 2005, 7, 4907.

[13] Li, P.; Lu, B.; Fu, C.; Ma, S. Adv. Synth. Catal. 2013, 355, 1255.

[14] Handa, S.; Andersson, M. P.; Gallou, F.; Reilly, J.; Lipshutz, B. H. Angew. Chem., Int. Ed. 2016, 55, 4914.

[15] (a) Bhilare, S.; Gayakhe, V.; Ardhapure, A. V.; Sanghavi, Y. S.; Schulzke, C.; Borozdina, Y.; Kapdi, A. R. RSC Adv. 2016, 6, 83820. (b) Girase, T. R.; Kapdi, A. R. Chem. Asian J. 2019, 14, 2611.

[16] For Hiesro and Doucet's selected reference, see:

(a) Hierso, J.-C.; Fihri, A.; Amardeil, R.; Meunier, P.; Doucet, H.; Santelli, M.; Donnadieu, B. Organometallics 2003, 22, 4490.

For Hoshi and Hagiwara's selected reference, see:

(b) Hoshi, T.; Nakazawa, T.; Saitoh, I.; Mori, A.; Suzuki, T.; Sakai, J.-I.; Hagiwara, H. Org. Lett. 2008, 10, 2063.

For Yu and Liu's selected reference, see:

(c) Mao, S.-L.; Sun, Y.; Yu, G.-A.; Zhao, C.; Han, Z.-J.; Yuan, J.; Zhu, X.; Yang, Q.; Liu, S.-H. Org. Biomol. Chem. 2012, 10, 9410.

For Doherty's selected reference, see:

(d) Doherty, S.; Smyth, C. H.; Knight, J. G.; Hashmi, S. A. K. Nat. Protocols 2012, 7, 1870 .

For Fossey's selected reference, see:

(e) Zhao, Y.; van Nguyen, H.; Male, L.; Craven, P.; Buckley, B. R.; Fossey, J. S. Organometallics 2018, 37, 4224.

[17] Wong, S. M.; So, C. M.; Chung, K. H.; Lau, C. P.; Kwong, F. Y. Eur. J. Org. Chem. 2012, 4172.

[18] For selected references, see:

(a) Wang, Z.; Guo, W. In Homogeneous Catalysis for Unreactive Bond Activation, Ed.: Shi, Z., John Wiley \& Sons, Hoboken, NJ, 2015, p. 1.

(b) Braunstein, P.; Naud, F. Angew. Chem., Int. Ed. 2001, 40, 680

(c) Weng, Z.; Teo, S.; Hor, T. S. A. Acc. Chem. Res. 2007, 40, 676.

(d) Zhang, W.-H.; Chien, S. W.; Hor, T. S. A. Coord. Chem. Rev. 2011, 255, 1991.

(e) Guram, A. S. Org. Process Res. Dev. 2016, 20, 1754.

[19] Kwong, F. Y.; Chan, A. S. C. Synlett 2008, 1440.

[20] (a) Old, D. W.; Wolfe, J. P.; Buchwald, S. L. J. Am. Chem. Soc. 1998, 120, 9722.

(b) Amatore, C.; Fuxa, A.; Jutand, A. Chem.-Eur. J. 2000, 6, 1474.

[21] (a) Bei, X.; Crevier, T.; Guram, A. S.; Jandeleit, B.; Powers, T. S.; Turner, H. W.; Uno, T.; Weinberg, W. H. Tetrahedron Lett. 1999, 40,3855 . (b) Bei, X.; Turner, H. W.; Weinberg, W. H.; Guram, A. S.; Petersen, J. L. J. Org. Chem. 1999, 64, 6797.

[22] Teo, S.; Weng, Z.; Hor, T. S. A. Organometallics 2006, 25, 1199.

[23] (a) Kwong, F. Y.; Lam, W. H.; Yeung, C. H.; Chan, K. S.; Chan, A. S. C. Chem. Commun. 2004, 1922.

(b) Chen, G.; Lam, W. H.; Fok, W. S.; Lee, H. W.; Kwong, F. Y. Chem. Asian J. 2007, 2, 306.

(c) So, C. M.; Yeung, C. C.; Lau, C. P.; Kwong, F. Y. J. Org. Chem. 2008, 73, 7803.

[24] (a) Dai, W.-M.; Li, Y.; Zhang, Y.; Lai, K. W.; Wu, J. Tetrahedron Lett. 2004, 45, 1999.

(b) Dai, W.-M.; Zhang, Y. Tetrahedron Lett. 2005, 46, 1377.

(c) Dai, W.-M.; Li, Y.; Zhang, Y.; Yue, C.; Wu, J. Chem.-Eur. J. 2008, 14, 5538 .

[25] Ullah, E.; McNulty, J.; Robertson, A. Tetrahedron Lett. 2009, 50, 5599.

[26] (a) Schaarschmidt, D.; Lang, H. Eur. J. Inorg. Chem. 2010, 4811. (b) Schaarschmidt, D.; Lang, H. ACS Catal. 2011, 1, 411

[27] (a) Chow, W. K.; So, C. M.; Lau, C. P.; Kwong, F. Y. J. Org. Chem. 2010, 75, 5109.

(b) Wong, P. Y.; Chow, W. K.; Chung, K. H.; So, C. M.; Lau, C. P.; Kwong, F. Y. Chem. Commun. 2011, 47, 8328.

(c) To, S. C.; Kwong, F. Y. Chem. Commun. 2011, 47, 5079.

(d) Chow, W. K.; Yuen, O. Y.; So, C. M.; Wong, W. T.; Kwong, F. Y. J. Org. Chem. 2012, 77, 3543.

(e) Leung, M. P.; Choy, P. Y.; Lai, W. I.; Gan, K. B.; Kwong, F. Y. Org. Process Res. Dev. 2019, 23, 1602.

[28] Armarego, W. L. F. Purification of Laboratory Chemicals, Butterworth-Heinemann, Oxford, UK, 2017.

[29] Choy, P. Y.; Yuen, O. Y.; Leung, M. P.; Chow, W. K.; Kwong, F. Y. Eur. J. Org. Chem. 2020, 2846.

[30] Lee, H. W.; Lam, F. L.; So, C. M.; Lau, C. P.; Chan, A. S. C.; Kwong, F. Y. Angew. Chem., Int. Ed. 2009, 48, 7436.

[31] Wu, Y.; Choy, P. Y.; Kwong, F. Y. Org. Biomol. Chem. 2014, 12 , 6820.

[32] Chung, K. H.; So, C. M.; Wong, S. M.; Luk, C. H.; Zhou, Z.; Lau, C. P.; Kwong, F. Y. Chem. Commun. 2012, 48, 1967.

[33] McNulty, J.; Capretta, A.; Wilson, J.; Dyck, J.; Adjabeng, G.; Robertson, A. Chem. Commun. 2002, 1986.

[34] So, C. M.; Lau, C. P.; Kwong, F. Y. Org. Lett. 2007, 9, 2795.

[35] Mingji, D.; Liang, B.; Wang, C.; You, Z.; Xiang, J.; Dong, G.; Chen, J.; Yang, Z. Adv. Synth. Catal. 2004, 346, 1669.

[36] Zhang, J.; Zhao, L.; Song, M.; Mak, T. C. W.; Wu, Y. J. Organomet. Chem. 2006, 691, 1301. 